\title{
Management Strategies for Barley Yellow Dwarf on Winter Wheat in Kansas
}

William W. Bockus, Erick D. De Wolf, and Timothy C. Todd, Department of Plant Pathology, Kansas State University, Manhattan 66506

Accepted for publication 4 May 2016. Published 7 June 2016.

\section{ABSTRACT}

Bockus, W. W., De Wolf, E. D., and Todd, T. C. 2016. Management strategies for barley yellow dwarf on winter wheat in Kansas. Plant Health Prog. 17:122-127.

Barley yellow dwarf (BYD) is one of the most important wheat diseases in the state of Kansas. Several methods of disease management have been recommended to mitigate losses from BYD including the use of seedtreatment insecticides, delayed planting of winter wheat, and deploying cultivars with resistance to BYD. The goal of this research was to quantify the impact of these three management strategies, alone and in combination, on BYD disease progress and grain yields in Kansas. When field experiments were averaged over four years, treating seed with the insecticide imidacloprid (Gaucho) reduced the daily increase in the area under the disease progress curve (AUDPC) by $35.0 \%$ and corresponding yield losses from BYD by $16.4 \%$. Compared with early planting, late planting reduced AUDPC by $47.9 \%$ and corresponding yield losses by $57.5 \%$. Planting a moderately resistant cultivar reduced AUDPC by $80.9 \%$ and corresponding yield losses by $72.6 \%$ compared with a susceptible cultivar. When all three BYD management methods were combined, BYD was reduced by $95.2 \%$ and yield losses reduced by $97.1 \%$ when compared with not using any of the management methods. Therefore, integrating management practices can result in high levels of control of BYD in Kansas.

\section{SIGNIFICANCE OF BARLEY YELLOW DWARF IN KANSAS}

Barley yellow dwarf (BYD) is an important disease, occurs worldwide (Burnett 1984; Lister and Ranieri 1995; Plumb 1983), and is the fifth most important wheat disease in Kansas (Appel et al. 2015). That state is usually the nation's number one producer of wheat and often plants about 4 million hectares. BYD is caused by several strains of viruses including Barley yellow dwarf virus (BYDV) and Cereal yellow dwarf virus (CYDV). The strain most often detected in wheat in Kansas is PAS (BYDV) although PAV (BYDV) and RPV (CYDV) can also occur in significant amounts in certain fields (Acosta-Leal et al. 2013). The most common vectors of these viruses are the bird cherry-oat aphid (Rhopalosiphum padi) or the greenbug (Schizaphis graminum) (Fig. 1) (Gildow 1987; Power and Gray 1995).

The most typical symptom of BYD infection is discoloration of leaves with yellow discoloration the most common (Fig. 2); however, certain wheat genotypes also show orange, red, or purple leaf discoloration (Fig. 3). In Kansas, symptoms typically begin to appear in April as the wheat goes through the jointing growth stage. From that point, the percentage of plants displaying symptoms will usually increase until natural senescence begins. After heading, other symptoms can appear such as tiller stunting and darkening of the heads at maturity. The stunting symptom is usually associated with early infections of the wheat plant in the fall (Goulart et al. 1989).

BYD can cause significant yield losses in wheat (Fig. 4). For example, yields were reduced by $46 \%$ in BYD-infected wheat and $58 \%$ when virus-infected wheat was simultaneously infested with $R$. padi (Riedell et al. 1961). There are several other reports

Corresponding author: W.W. Bockus. Email: bockus@ksu.edu. documenting yield losses between 32 and 53\% (Herbert et al. 1999, 34\%; Hoffman and Kolb 1998, 36\%; McKirdy and Jones 1996, 43\%; McKirdy et al. 2002, 33 to 53\%; Perry et al. 2000, $35 \%$; and Weisz et al. 2005, 32\%). Another report (Patterson et al. 1990) estimated regional losses due to BYD of 2 to $10 \%$.

Similar losses (22 to 49\%) have been reported for BYD in winter wheat in Kansas (Bockus 1994; Bockus 1997; Bockus and De Wolf 2013; Bockus and De Wolf 2014; Bockus et al. 2015).

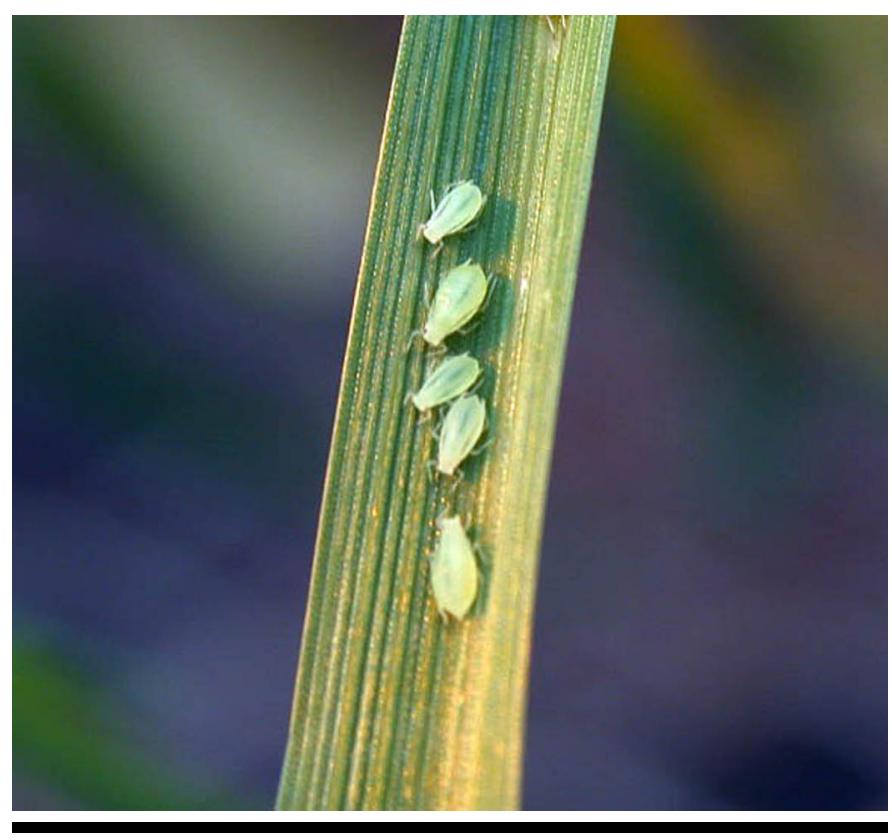

FIGURE 1

Example of vector of barley yellow dwarf (Schizaphis graminum). 
Recently, Gaunce and Bockus (2015) estimated losses for highly susceptible cultivars over a seven-year period in early-planted field experiments. Loss estimates were significant each year and ranged from $25 \%$ to $86 \%$ depending upon the year with an average loss of 49\% (Gaunce and Bockus 2015). Therefore, BYD can cause significant losses in early-planted winter wheat in Kansas in virtually any year.

There are several different methods to control BYD. The three most common methods are: (i) control of vector populations; (ii) cultural practices to avoid peak vector activity including adjusting planting dates; and (iii) deployment of disease resistance (Gray 2010). The goal of this research was to quantify the impact of these three methods alone and in combination to determine the best strategy for wheat producers in Kansas to avoid large yield losses due to BYD.

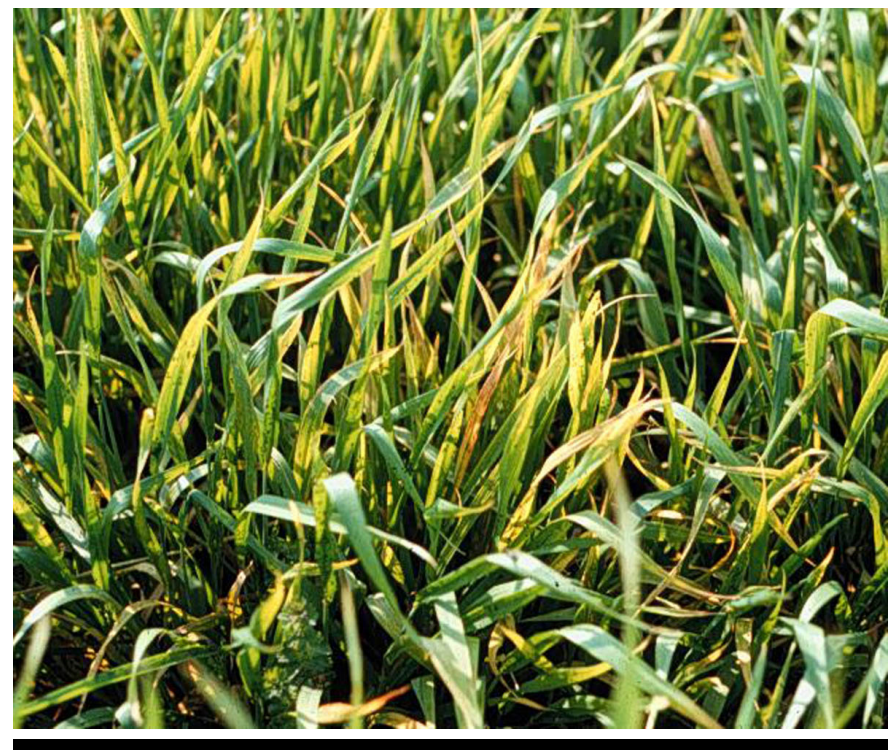

FIGURE 2

Yellow leaf symptoms on wheat due to infection by Barley yellow dwarf virus.

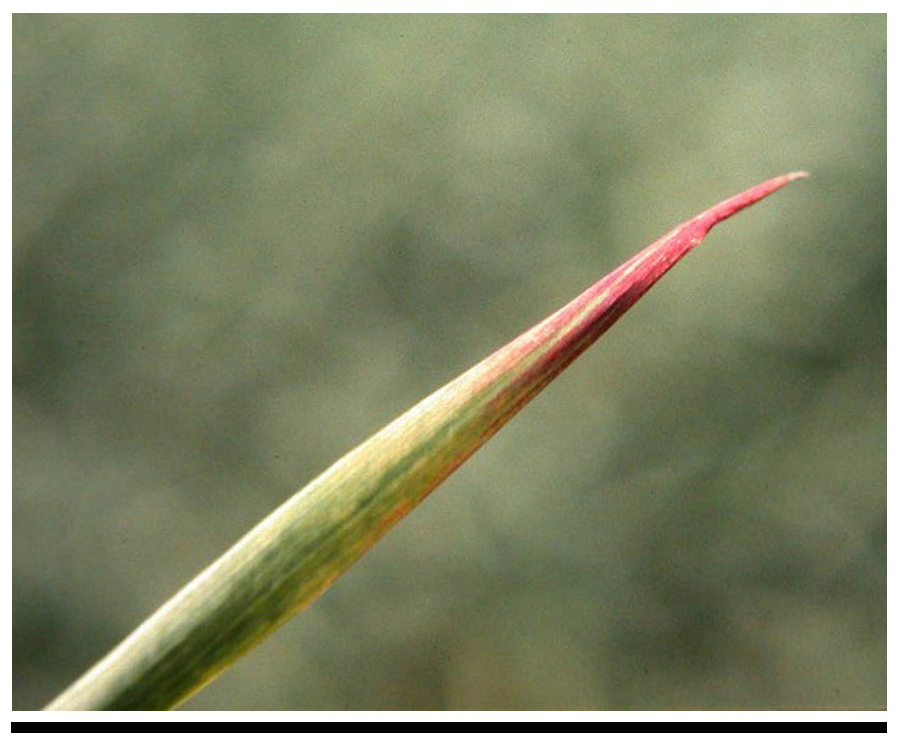

FIGURE 3

Red leaf symptoms on wheat due to infection by Barley yellow dwarf virus.

\section{EXPERIMENTS TO QUANTIFY DISEASE MANAGEMENT}

\section{STRATEGIES}

The experiments were conducted over four seasons (2011$2015)$ in Chase silty clay loam $(\mathrm{pH}=6.5)$ near Manhattan, KS. Each year, two identical experiments were planted near each other with an early ( 9 to 13 September) or late (10 to 18 October) planting date. The two planting dates represented the two extremes of when wheat would normally be planted in Kansas. The early planting date was about three weeks earlier than the normal date and mimicked what producers would do if they planned to graze the wheat (Shroyer et al. 1997). The late planting date was about two weeks after the normal date and mimicked what producers would do if they were delaying planting to control grassy weeds, avoid insect and disease problems, waiting for adequate soil moisture, or planting wheat "double-crop" after soybeans (Shroyer et al. 1997).

Experimental design was a randomized split-plot with three to eight cultivars as whole plots, three levels of disease as sub-plots, and five replications. Sub-plots were 1.5 by $4.6 \mathrm{~m}$. Three of the cultivars were common to all years, Everest (moderately resistant check), Armour (intermediate check), and Art (susceptible check). They have KSU Cooperative Extension ratings for reaction to BYD of 4, 6 , and 8 , respectively, where a rating of 1 is highly resistant and a rating of 9 is highly susceptible (De Wolf et al. 2015). The three levels of disease were achieved by: (1) sowing non-treated seed with plants receiving no foliar insecticide (diseased control); (2) seed treated with Gaucho 600 [48.7\% imidacloprid, $1.56 \mathrm{ml} / \mathrm{kg}$ ( $2.4 \mathrm{fl} \mathrm{oz} / \mathrm{cwt})$, highest label rate] and plants receiving no foliar insecticide (Gaucho-treated); or (3) seed treated with Gaucho and plants receiving multiple applications of the foliar insecticide cyfluthrin (Decathlon 20W, $263 \mathrm{~g} / \mathrm{ha}$ ) with $0.125 \%$ Induce surfactant (McKirdy and Jones 1996). The third level of disease was designated "healthy control." For this treatment, eight or nine foliar insecticide applications were made each year beginning between 23 September and 2 October and ending between 13 April and 9 May. Applications were about two weeks apart with a lengthy period during the winter when there were no applications due to the extremely low temperatures that stopped aphid activity and when the wheat was dormant. The use of "healthy control" plots is unusual for experiments with BYD but was necessary to obtain more accurate determinations of yield losses, a major component of this research.

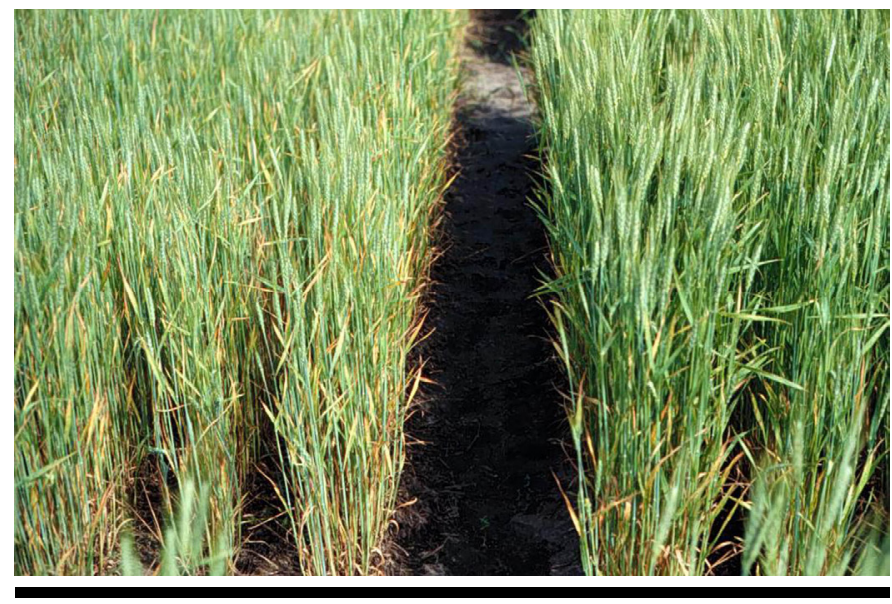

FIGURE 4

Impact of barley yellow dwarf on winter wheat; diseased plot on the left and healthy plot on the right. 
The incidence of BYD caused by natural infections was visually estimated for each plot between three and six times depending upon the year. At each evaluation date, visual estimations of the percentage plants showing leaf symptoms of BYD were recorded. Estimations began when symptoms first appeared and continued at weekly intervals until the beginning of natural senescence. Harvest was between 5 June and 8 July with a plot combine. For analyses concerning disease progress, the daily increase in the area under the disease progress curve (AUDPC) was calculated. The following formula was used: $\{$ [(rating on first rating day plus rating on second rating day) divided by 2] times the number of days between rating day 1 and rating day 2 \} plus $\{[$ (rating on second rating day + rating on third rating day) divided by 2] times the number of days between rating day 2 and rating day 3$\}$, etc., until all of the rating days were included in the formula. The result was then divided by the total number of days between rating day 1 and the last rating day to get a value for the daily increase in AUDPC for that plot.

The data were analyzed as a split-split-plot, with planting date as the whole-plot treatment, cultivar as the subplot treatment, and disease level as sub-subplot treatment. Planting date, cultivar, and disease level were treated as fixed effects, while year was treated as a random effect. Only cultivars that were included for at least three of the four years were included in the analyses. Disease pressure and grain yields were different each year and the inherent yield potential of each cultivar differed. Therefore, to standardize the data across all years, yield loss was expressed as a proportion of the healthy control in each whole plot [(healthy yield - yield) / healthy yield]. Analysis of disease progress (AUDPC) was performed using SAS (SAS Institute Inc., Cary, NC) PROC GLIMMIX and the Poisson distribution. Analysis of yield loss was performed using SAS PROC MIXED. Model fit was confirmed by residual evaluation in all cases.

\section{DISEASE PRESSURE AND RATINGS}

Infection by BYDV occurred due to the natural activity of various aphid species (mostly the bird cherry-oat aphid, Rhopalosiphum padi). The vectors are thought to come from native perennial grasses and volunteer host plants (McKirdy and Jones 1993; Jones et al. 1990). Severe BYD pressure occurred during 2012, moderate pressure during 2013, light pressure during 2014, and moderate pressure during 2015. Mean incidences recorded on the susceptible cultivar Art for the nontreated controls for the early planting date were 63, 33, 11, and $21 \%$ for 2012-2015, respectively. When averaged across all years for the susceptible cultivar Art for the early planting date, disease incidence values on the healthy control plants were only $5.9 \%$ compared with an average value of $31.9 \%$ on non-treated plants. This indicated that the seed treatment coupled with the foliar insecticide sprays resulted in high levels of control, $81.4 \%$ reduction in symptoms. Nevertheless, the estimates for yield losses reported here are slightly lower than the actual losses because control of disease in the "healthy" plots was not $100 \%$.

\section{RELATIONSHIP BETWEEN BYD DISEASE PROGRESS AND WHEAT YIELD LOSS}

Proportional yield loss across years was related to BYD disease progress using simple linear regression (Fig. 5). The model predicted a $\sim 1 \%$ loss in yield for each stepwise increase in disease progress and explained $66 \%$ of the total variation in the data $(P<0.0001)$. This corroborates the findings of Gaunce and Bockus (2015) where there were significant correlations between disease and grain yield. Therefore, visual estimates of the percentage symptomatic plants are useful to predict the damage from BYD in Kansas.

\section{EFFECT OF SEED TREATMENT}

Seed-treatment insecticides have been shown to reduce losses from BYD in wheat in other states by affecting the aphid vectors during the early portion of the wheat plant's growth cycle. For example, Gourmet et al. (1996) reported yield increases of up to $21 \%$ with imidacloprid-treated seed on BYD-susceptible cultivars in inoculated plots. Even in non-inoculated plots, yields were increased $14 \%$ over plots sown with non-treated seed due to natural infection of BYD. Royer et al. (2005) reported that although wheat grain yields were increased with insecticide seed treatments, economic returns were inconsistent. However, if aphids were viruliferous, positive economic return was consistent in their experiments. Therefore, there are times when effective management of BYD can be achieved using insecticide seed treatments.

Results presented here also showed that imidacloprid-treated seed could lessen BYD in Kansas and result in a corresponding yield increase. When averaged over all cultivars and all years, seed treatment with Gaucho insecticide significantly $(P=0.0001)$ reduced the daily increase in AUDPC compared with the nontreated check (Table 1). The daily value was reduced from 10.54 to 6.85 , a $35.0 \%$ reduction. Similarly, across all cultivars and years, Gaucho seed treatment significantly $(P=0.0200)$ reduced yield loss from $14.24 \%$ for the non-treated check to $11.90 \%$, a $16.4 \%$ reduction. The average yield response compared with the diseased check was $117 \mathrm{~kg} / \mathrm{ha}$. This would pay for the cost of the treatment if the cash grain price was above $\$ 11.90 / 100 \mathrm{~kg}$ (\$3.24/bu) (Table 2). However, yield changes due to Gaucho were highly variable for individual cultivars at certain planting dates and during certain years (Fig. 6). It is unknown what factors are involved in the performance of Gaucho seed treatment that would allow predictions of when economic returns would be achieved from this management strategy. Nevertheless, data reported here indicate that seed treatment with Gaucho can be a viable choice for the management of BYD in Kansas.

\section{EFFECT OF PLANTING DATE}

The barley yellow dwarf pathogens are only transmitted by their aphid vectors (Gildow 1987; Jensen and D'Arcy 1995). Therefore, selection of a planting date to avoid peak aphid flights can help lessen the incidence and damage of BYD (Anonymous

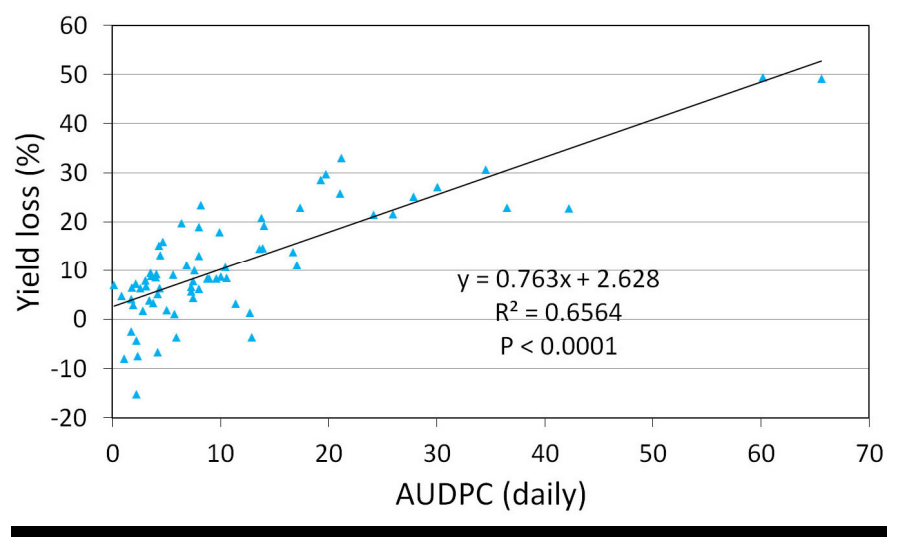

\section{FIGURE 5}

Relationship between daily increase in barley yellow dwarf (area under the disease progress curve $=$ AUDPC) and yield loss from the disease . 
1990; Gray 2010; Royer et al. 2005). For winter wheat, that would mean delaying planting in the fall until cooler temperatures have lessened aphid activity.

Results presented here from four years showed that late planting of winter wheat in Kansas reduced BYD compared with early planting (Tables 3 and 4). There was a significant reduction

\section{TABLE 1}

Effect of different insecticide treatments on daily increases in barley yellow dwarf (AUDPCX).

\begin{tabular}{|c|c|c|c|}
\hline \multirow[t]{2}{*}{ Treatment } & & Gauchoy & Non-treated \\
\hline & AUDPC & 6.85 & 10.54 \\
\hline Healthy check ${ }^{z}$ & 2.57 & $<0.0001$ & $<0.0001$ \\
\hline Gaucho & 6.85 & & 0.0001 \\
\hline
\end{tabular}

${ }^{x}$ Area under the disease progress curve.

y Seed treated with Gaucho insecticide $(157 \mathrm{ml} / 100 \mathrm{~kg}=2.4 \mathrm{fl} \mathrm{oz} / \mathrm{cwt})$.

${ }^{\mathrm{z}}$ Seed treated with Gaucho insecticide and foliage sprayed several times with Decathlon insecticide.

\begin{tabular}{ccc}
\multicolumn{3}{c}{ Economic returns from seed treatment } \\
with Gaucho 600.
\end{tabular}

${ }^{\mathrm{x}}$ Current cost of Gaucho 600 is $\$ 132 /$ liter ( $\$ 500 /$ gallon); treatment rate was $157 \mathrm{ml} / 100 \mathrm{~kg}(2.4 \mathrm{fl} \mathrm{oz} / \mathrm{cwt})$.

y Average yield increase from treatment with Gaucho was $117 \mathrm{~kg} / \mathrm{ha}$ (1.74 bu/acre). in disease for four of the five cultivars (Table 3). Only

'Endurance' did not show a significant reduction in disease with late planting although the $42.4 \%$ reduction for that cultivar was close to significance $(P=0.1321)$. When all cultivars were combined, the daily AUDPC value was reduced by $47.9 \%$ with late planting (Table 3). Yield losses due to BYD were also shown to be reduced with late planting on 3 of the five cultivars (Table 4). Reductions for these cultivars ranged from 51.0 to $63.4 \%$. Also, when all cultivars were combined, the loss was reduced $(P=0.0847)$ from 18.3 to $7.8 \%$, a reduction of $57.5 \%$. Therefore, delayed planting, when compared with early planting, can have a large impact on BYD and resulting yield losses. Nevertheless,

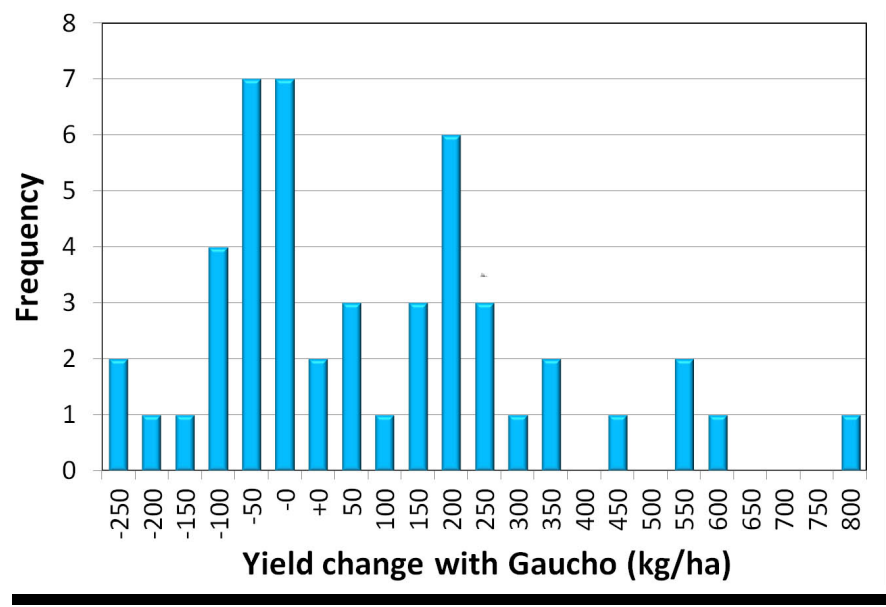

FIGURE 6

Frequency of changes in yield ( $\mathrm{kg} / \mathrm{ha}$ ) from seed treatment with Gaucho 600 over all cultivars, planting dates, and years. The average change was $117 \mathrm{~kg} / \mathrm{ha}$.

\begin{tabular}{|c|c|c|c|c|c|}
\hline \multirow{2}{*}{ Cultivar } & 10 & : & $\begin{array}{l}\text { TABLE } 3 \\
\text { yellow dwarf (area }\end{array}$ & the disease pr & urve, AUDPC). \\
\hline & \multicolumn{2}{|c|}{ Planting date ${ }^{\mathrm{w}}$} & Reduction (number ${ }^{\mathbf{y}}$ ) & Reduction $\left(\% 3^{\mathbf{z}}\right)$ & Early vs. late ( $P$ value \\
\hline Armour & 9.27 & 5.12 & 4.15 & 44.77 & 0.0321 \\
\hline Art & 13.34 & 7.47 & 5.87 & 44.00 & 0.0279 \\
\hline Endurance & 6.14 & 3.54 & 2.60 & 42.35 & 0.1321 \\
\hline All & 7.91 & 4.12 & 3.79 & 47.91 & 0.0568 \\
\hline
\end{tabular}

${ }^{w}$ Early was about 3 weeks earlier than normal and late was about 2 weeks later than the normal planting date.

y Early minus late.

${ }^{\mathrm{z}}$ Early minus late divided by early times 100 .

\begin{tabular}{|c|c|c|c|c|c|}
\hline \multirow{2}{*}{ Cultivar } & \multicolumn{4}{|c|}{$\begin{array}{c}\text { TABLE } 4 \\
\text { Effect of planting date on yield losses }(\% \mathrm{w}) \text { due to barley yellow dwarf. }\end{array}$} & \multirow{2}{*}{ Early vs. late ( $P$ value) } \\
\hline & \multicolumn{2}{|c|}{ Planting date ${ }^{x}$} & Reduction (numbery) & Reduction $\left(\%{ }^{\mathbf{z}}\right)$ & \\
\hline Armour & 13.74 & 7.77 & 5.97 & 43.45 & 0.2769 \\
\hline Art & 25.34 & 12.41 & 12.93 & 51.03 & 0.0251 \\
\hline Endurance & 19.43 & 7.72 & 11.71 & 60.27 & 0.0606 \\
\hline All & 18.34 & 7.80 & 10.54 & 57.47 & 0.0847 \\
\hline
\end{tabular}

${ }^{\mathrm{w}}$ Relative to the healthy check.

${ }^{x}$ Early was about 3 weeks earlier than normal and late was about 2 weeks later than the normal planting date.

y Early minus late.

${ }^{\mathrm{z}}$ Early minus late divided by early times 100 . 
TABLE 5

Comparisons ( $P$ values) of daily increases in barley yellow dwarf (AUDPCy) between wheat cultivars.

\begin{tabular}{|c|c|c|c|c|c|c|}
\hline \multirow[t]{2}{*}{ Cultivar } & & & Art & Endurance & Everest & PostRock \\
\hline & Resistance $^{\mathrm{Z}}$ & & 8 & 5 & 4 & 7 \\
\hline Armour & 6 & 6.88 & 0.0038 & 0.0371 & $<0.0001$ & 0.1945 \\
\hline Endurance & 5 & 4.66 & - & - & 0.0006 & 0.0004 \\
\hline Everest & 4 & 1.91 & - & - & - & $<0.0001$ \\
\hline
\end{tabular}

y Area under the disease progress curve.

${ }^{\mathrm{z}}$ Extension rating ( 1 to 9 ) where $1=$ highly resistant and $9=$ highly susceptible.

\begin{tabular}{|c|c|c|c|c|c|c|}
\hline \multirow{4}{*}{ Cultivar } & \multicolumn{6}{|c|}{$\begin{array}{c}\text { TABLE } 6 \\
\text { Comparisons ( } P \text { values) of yield losses }(\% x) \text { due to barley yellow dwarf between wheat cultivars. }\end{array}$} \\
\hline & & & Art & Endurance & Everest & PostRock \\
\hline & Resistance $^{\mathrm{Z}}$ & & 8 & 5 & 4 & 7 \\
\hline & & Yield loss (\%) & 18.87 & 13.58 & 5.17 & 16.99 \\
\hline Armour & 6 & 10.75 & 0.0074 & 0.3589 & 0.0539 & 0.0515 \\
\hline Art & 8 & 18.87 & - & 0.0937 & $<0.0001$ & 0.5373 \\
\hline Endurance & 5 & 13.58 & - & - & 0.0112 & 0.2919 \\
\hline Everest & 4 & 5.17 & - & - & - & 0.0008 \\
\hline
\end{tabular}

${ }^{y}$ Relative to the healthy check.

${ }^{\mathrm{z}}$ Extension rating ( 1 to 9 ) where $1=$ highly resistant and $9=$ highly susceptible.

decisions to plant late should take into consideration the goals of the producer and the possible yield penalty from planting outside of the optimum time (Shroyer et al. 1997).

\section{EFFECT OF CULTIVAR RESISTANCE}

Arguably the best management practice for BYD is the planting of resistant cultivars (Gray 2010). In Kansas, several winter wheat cultivars have been released in recent years with improved resistance to BYD (De Wolf et al. 2015). One of these cultivars, Everest, has increased in popularity so that it has been the mostplanted cultivar in the state for the past three years. Estimations of the impact of this resistance on yield showed a $73 \%$ reduction in yield loss from the resistance level in Everest when compared with a highly susceptible cultivar (Gaunce and Bockus 2015). Everest was used each year as the moderately resistant check in experiments reported here, where it had significant reductions in disease severity relative to the intermediate and susceptible cultivars (Table 5). Everest had 59.0 to $80.9 \%$ less disease than these cultivars. Moderately resistant Everest also had less yield loss from BYD compared with all of the other intermediate and susceptible cultivars (Table 6). Losses were reduced 51.9 to $72.6 \%$ compared with the other cultivars. This latter number corroborates the $73 \%$ reduction observed by Gaunce and Bockus (2015) for moderately resistant Everest versus susceptible cultivars. Everest is rated a 4 on the 1-to- 9 scale where 1 is highly resistant and 9 is highly susceptible; therefore, there is still room for significant increases in the level of resistance in wheat cultivars. Nevertheless, these results indicate that even moderate levels of resistance can have a large impact on disease development and resulting yield losses in Kansas.

\section{INTEGRATION OF ALL THREE MANAGEMENT PRACTICES}

While each of the three management practices by themselves had significant impacts on development of BYD and associated yield losses, it is also important to know what impact they would have when combined. In these experiments, there were no significant cultivar-by-treatment-by-planting date interactions for daily increases in AUDPC $(P=0.9976)$ or yield loss $(P=0.5525)$ indicating that the different management practices were additive. Therefore, comparisons were made between a susceptible cultivar (Art) sown with non-treated seed at an early planting date with a moderately resistant cultivar (Everest) sown with seed treated with Gaucho insecticide at a late planting date. Using none of the best management practices resulted in highly significant disease and loss values while using all three management practices resulted in disease and yield loss values that were not significantly different from zero (Table 7). Combining all three management practices resulted in a $95.2 \%(P<0.0001)$ reduction in BYD and a $97.1 \%(P<0.0001)$ reduction in yield loss (Table 7). Therefore, using integrated pest management of BYD can result in high levels of control. Wheat producers in Kansas should consider each of the three management practices discussed here and, in situations where BYD is expected to be problematic, they should consider integrating all three practices.

\begin{tabular}{|c|c|c|}
\hline \multicolumn{3}{|c|}{$\begin{array}{c}\text { TABLE } 7 \\
\text { Effect of three combined management methods on barley } \\
\text { yellow dwarf (AUDPCV) and yield losses.w }\end{array}$} \\
\hline & $\begin{array}{c}\text { AUDPC } \\
\text { (value per day) }\end{array}$ & Pvalue ${ }^{z}$ \\
\hline $\begin{array}{l}\text { Art, NT, early } \\
\text { Everest, Gaucho, latey } \\
\text { Reduction }(\%)\end{array}$ & $\begin{array}{l}25.57 \\
1.23 \\
95.2\end{array}$ & $\begin{array}{r}<0.0001 \\
0.7069 \\
<0.0001\end{array}$ \\
\hline & Yield loss (\%) & Pvalue ${ }^{z}$ \\
\hline $\begin{array}{l}\text { Art, NT, early } \\
\text { Everest, Gaucho, late } \\
\text { Reduction }(\%)\end{array}$ & $\begin{array}{r}26.26 \\
0.77 \\
97.1\end{array}$ & $\begin{array}{r}0.0002 \\
0.8995 \\
<0.0001\end{array}$ \\
\hline
\end{tabular}

${ }^{\mathrm{v}}$ Area under the disease progress curve.

${ }^{\mathrm{w}}$ Relative to the healthy check.

${ }^{x}$ Cultivar was Art, non-treated seed, early planting.

y Cultivar was Everest, seed treated with Gaucho, late planting.

${ }^{\mathrm{z}}$ Test whether the value was different from zero. 


\section{ACKNOWLEDGMENTS}

We thank the Kansas Wheat Commission for funding. This manuscript is contribution 16-165-J from the Kansas Agricultural Experiment Station

\section{LITERATURE CITED}

Acosta-Leal, R., Hervey, K. L., Whitfield, A. E., Bockus, W. W., and Rotenberg, D. 2013 Genetic diversity of Barley yellow dwarf virus (BYDV) populations in Kansas wheat fields. Phytopathology 103:S3.1. http://dx.doi.org/10.1094/PHYTO-103-9-S3.1

Anonymous. 1990. Integrated Pest Management for Small Grains. Pub. 3340. Statewide Integrated Pest Manage. Proj., Div. of Agric. and Natural Resources. Univ. of Calif., Davis.

Appel, J. A., De Wolf, E., Todd, T., and Bockus, W. W. 2015. Preliminary 2015 Kansas Wheat Disease Loss Estimates. Kansas Coop. Plant Dis. Survey Rep. http://agriculture.ks.gov/docs/default-source/pp-disease-reports-2012/2015ks-wheat-disease-loss-estimates35b3d4002e6262e1aa5bff0000620720.pdf.

Bockus, W. W. 1994. Effect of Gaucho seed treatment and Furadan on barley yellow dwarf of winter wheat, 1993. Fung. Nema. Tests 49:295.

Bockus, W. W. 1997. Effect of Gaucho seed treatment on barley yellow dwarf of winter wheat, 1996. Fung. Nema. Tests 52:323.

Bockus, W., and De Wolf, E. 2013. Effects of planting date, cultivar, and imidacloprid seed treatment on barley yellow dwarf of winter wheat, 2012. Plant Dis. Manag. Rep. 7:CF005. doi:10.1094/PDMR07.

Bockus, W. W., and De Wolf, E. D. 2014. Effects of planting date, cultivar, and imidacloprid seed treatment on barley yellow dwarf of winter wheat, 2013. Plant Dis. Manag. Rep. 8:CF026. doi:10.1094/PDMR08.

Bockus, W. W., De Wolf, E. D., and Todd, T. C. 2015. Effects of planting date, cultivar, and imidacloprid seed treatment on barley yellow dwarf of winter wheat, 2012-14. Plant Dis. Manag. Rep. 9:CF010. doi:10.1094/PDMR09.

Burnett, P. A. 1984. Barley yellow dwarf. Pages 6-13 in: Barley Yellow Dwarf. Proc. Workshop, CIMMYT. Dec. 1983. P. A. Burnett, ed. CIMMYT, Mexico City, D.F., Mexico.

De Wolf, E. D., Bockus, W. W., and Whitworth, J. R. 2015. Wheat Variety Disease and Insect Ratings 2015. Publ. MF-991. Coop. Ext. Service, Kansas State Univ., Manhattan.

Gaunce, G. M., and Bockus, W. W. 2015. Estimating yield losses due to barley yellow dwarf on winter wheat in Kansas using disease phenotypic data. Plant Health Prog. 16:1-6. doi:10.1094/PHP-RS-14-0039.

Gildow, F. E. 1987. Barley yellow dwarf virus-aphid vector interactions associated with virus transmission and vector specificity. Pages 111-122 in: World Perspectives on Barley Yellow Dwarf. Proc. Int. Workshop, Udine, Italy, July 1987. P. A. Burnett, ed. CIMMYT, Mexico City, D.F., Mexico.

Goulart, L. R., Ohm, H. W., and Foster, J. E. 1989. Barley yellow dwarf symptom severity in oat affected by plant growth stage at infection and plot type. Crop Sci. 29:1412-1416.

Gourmet, C., Kolb, F. L., Smyth, C. A., and Pedersen, W. L. 1996. Use of imidacloprid as a seed-treatment insecticide to control barley yellow dwarf virus (BYDV) in oat and wheat. Plant Dis. 80:136-141.
Gray, S. M. 2010. Barley yellow dwarf. Pages 100-102 in: Compendium of Wheat Diseases and Pests. 3rd Ed. American Phytopathological Society, St. Paul, MN.

Herbert, D. A., Jr., Stromberg, E. L., Chappell, G. F., and Malone, S. M. 1999. Reduction of yield components by barley yellow dwarf infection in susceptible winter wheat and winter barley in Virginia. J. Prod. Agric 12:1,105-109.

Jensen, S. G., and D'Arcy, C. J. 1995. Effects of barley yellow dwarf virus on host plants. Pages 55-74 in: Barley Yellow Dwarf: 40 Years of Progress.

C. J. D'Arcy and P. A. Burnett, eds. American Phytopathological Society, St. Paul, MN.

Jones, R. A. C., McKirdy, and S. J., Shivas, R. G. 1990. Occurrence of barley yellow dwarf viruses in over-summering grasses and cereal crops in Western Australia. Aust. Plant Pathol. 19:90-96.

Lister, R. M., and Ranieri, R. 1995. Distribution and economic importance of barley yellow dwarf. Pages 29-53 in: Barley Yellow Dwarf Virus: Forty Years of Progress. C. J. D'Arcy and P. A. Burnett, eds. American Phytopathological Society, St. Paul, MN.

McKirdy, S. J., and Jones, R. A. C. 1993. Occurrence of barley yellow dwarf virus serotypes MAV and RMV in over-summering grasses. Aust. J. Agric. Res. 44:1195-1209.

McKirdy, S. J., and Jones, R. A. C. 1996. Use of imidacloprid and newer generation synthetic pyrethroids to control the spread of barley yellow dwarf luteovirus in cereals. Plant Dis. 80:895-901.

McKirdy, S. J., Jones, R. A. C., and Nutter, F. W., Jr. 2002. Quantification of yield losses caused by Barley yellow dwarf virus in wheat and oats. Plant Dis. 86:769-773.

Patterson, A. G., Shaner, G. E., Foster, J. E., and Ohm, H. W. 1990. A historical perspective for the establishment of research goals for wheat improvement. J. Prod. Agric. 3:30-38.

Perry, K. L., Kolb, F. L., Sammons, B., Lawson, C., Cisar, G., and Ohm, H. 2000. Yield effects of Barley yellow dwarf virus in soft red winter wheat. Phytopathology 90:1043-1048.

Plumb, R. T. 1983. Barley yellow dwarf virus - a global problem. Pages 185198 in: Plant Virus Epidemiology. R. T. Plumb and J. M. Thresh, eds. Blackwell Scientific, London.

Power, A. G., and Gray, S. M. 1995. Aphid transmission of barley yellow dwarf viruses: Interaction between viruses, vectors and host plants. Pages 259-283 in: Barley Yellow Dwarf: 40 Years of Progress. C. J. D'Arcy and P. A. Burnett, eds. American Phytopathological Society, St. Paul, MN.

Riedell, W. E., Kieckhefer, R. W., Haley, S. D., Langham, M. A. C., and Evenson, P. D. 1961. Winter wheat responses to bird cherry-oat aphids and barley yellow dwarf virus infection. Crop-Sci. 39:158-163.

Royer, T. A., Giles, K. L., Nyamanzi, T., Hunger, R. M., Krenzer, E. G., Elliot, N. C., Kindler, S. D., and Payton, M. 2005. Economic evaluation of the effects of planting date and application rate of imidacloprid for management of cereal aphids and barley yellow dwarf in winter wheat. J. Econ. Entomol. 98:95-102.

Shroyer, J. P., Kok, H., and Thompson, C. R. 1997. Planting practices. Pages 9-12 in: Wheat Production Handbook. Coop. Ext. Pub. C-529. Kansas State Univ., Manhattan, KS.

Weisz, R., Tarleton, B., Murphy, J. P., and Kolb, F. L. 2005. Identifying soft red winter wheat cultivars tolerant to Barley yellow dwarf virus. Plant Dis. 89:170-176. 